\title{
Tradisi dan Lingkungan Sosial Memengaruhi Dukungan Menyusui pada Bayi Berat Badan Lahir Rendah di Kota Malang
}

\section{Tradition and Social Environment Influence Breastfeeding Support on Low Birthweight in Malang}

\author{
Muladefi Choiriyah*, Elsi Dwi Hapsari**, Wiwin Lismidiati**
}

\begin{abstract}
*Program Studi Ilmu Keperawatan Fakultas Kedokteran, Universitas Brawijaya, Indonesia, **Program Studi Magister Keperawatan Fakultas Kedokteran, Universitas Gadjah Mada, Indonesia
\end{abstract}

\begin{abstract}
Abstrak
Berat badan lahir rendah (BBLR) merupakan salah satu penyebab utama kematian bayi di dunia. World Health Organization tahun 2003 telah merekomendasikan menyusui sebagai salah satu penanganan BBLR. Namun, ibu yang memiliki bayi BBLR mengalami kesulitan di awal persalinan. Selain itu, menyusui di Indonesia juga dipengaruhi oleh sosial dan budaya yang dipercayai sehingga memengaruhi keputusan ibu untuk memilih tetap menyusui atau tidak sama sekali di periode awal postpartum. Tujuan penelitian ini untuk mengeksplorasi makna pengalaman ibu untuk tetap menyusui bayi dengan BBLR. Penelitian kualitatif ini dengan pendekatan fenomenologi. Tujuh orang partisipan adalah ibu yang pernah menyusui bayi BBLR. Pengumpulan data dilakukan dengan wawancara mendalam semiterstruktur, observasi, dan data sekunder pada bulan Mei - Juni 2015. Analisis data menggunakan metode Colaizzi tahun 1978. Ditemukan empat tema, yaitu pengenalan menyusui sejak dini untuk bayi BBLR, pemberian makanan pendamping air susu ibu dini sebagai alternatif dalam mengatasi kesulitan menyusui, tradisi yang dipercayai, dan lingkungan sosial memengaruhi dukungan bagi ibu menyusui serta menerima menyusui sebagai bagian dari kodrat seorang perempuan. Menyusui bayi BBLR memiliki tingkat kesulitan yang tinggi serta adanya tradisi yang dipercayai keluarga dan pengaruh lingkungan sosial sangat memengaruhi dukungan yang diberikan kepada ibu dalam menyusui.

Kata kunci: Berat badan lahir rendah, menyusui, pengalaman ibu
\end{abstract}

\section{Abstract}

Low birthweight (LBW) is one of main causes of infant mortality in the world. World Health Organization in 2003 had recommended breastfeeding for LBW handling. However, LBW mothers face many difficulties during early postpartum period. Moreover, breastfeeding in Indonesia is also influenced by social and cultural belief, so it may influence mothers' decision whether remain breastfeeding or not in early postpartum period. This study aimed to explore the meaning of the experience of mothers to remain breastfeeding their LBW infants. This qualitative study was conducted using phenomenological approach. Seven participants were mothers ever breastfeeding their LBW infants. Data were collected through semi-structured in-depth interview, observation and secondary data on May - June 2015. Data analysis used Colaizzi method (1978). There were four themes found namely introduction of breastfeeding since early for LBW infants, granting of early complementary feeding as an alternative to overcome breastfeeding problem, cultural belief and social environment influencing support for breastfeeding mothers as well as accepting breastfeeding as the very nature of woman. Breastfeeding LBW infants has higher difficulty level, also any tradition family believe and social environment really affect support given to mothers in breastfeeding.

Keywords: Low birthweight, breastfeeding, mother's experience

\section{Pendahuluan}

Berat badan lahir rendah (BBLR) menjadi salah satu penyebab tingginya angka kematian bayi di dunia. Setiap tahun sekitar 20 juta BBLR lahir di dunia dan 96,5\% berada di negara berkembang termasuk Indonesia. ${ }^{1} \mathrm{Di}$ Indonesia, kelahiran BBLR mencapai 10,2\% pada tahun 2013. Provinsi Jawa Timur memiliki persentase kelahiran BBLR tertinggi di pulau Jawa sebesar 11,2\%.2 Penyebab kelahiran bayi BBLR sebagian besar karena kelahiran prematur $(67 \%)$ dan kecil masa kehamilan (KMK) $(33 \%)$. Bayi prematur memiliki organ dalam yang belum sempurna perkembangannya. Bayi prematur yang disertai BBLR akan sangat rentan terhadap masalah kesehatan yang berakibat kesakitan dan kematian. ${ }^{3}$

Korespondensi: Muladefi Choiriyah, Pogram Studi Ilmu Keperawatan, Fakultas Kedokteran Universitas Brawijaya, Gedung Biomedik Lantai 2 No.Telp: 0341567192.e-mail:defi.fk@ub.ac.id/muladefi@gmail.com 
Menyusui menjadi salah satu rekomendasi World Health Organization (WHO) tahun 2003 untuk penanganan BBLR. Bayi BBLR yang tidak mendapatkan air susu ibu (ASI) dan mendapatkan susu formula dua kali berisiko mengalami infeksi, seperti necrotizing enterocolitis, diare, dan infeksi saluran pernapasan. ${ }^{4-6}$ Sebuah penelitian di Jepang dari 115 bayi BBLR yang dirawat di Neonatal Intensive Care Unit (NICU), prevalensi pemberian ASI saja atau ASI eksklusif ketika keluar dari NICU hanya sebesar $22,6 \%$ atau sebanyak 26 bayi, sedangkan $77,4 \%$ atau sebanyak 89 bayi diberikan ASI campur susu formula/susu formula saja ketika keluar dari NICU. ${ }^{7}$ Sedangkan di Indonesia, capaian ASI eksklusif secara nasional hanya 30,2\%.8 Kesulitan menyusui termasuk pada bayi BBLR memungkinkan berkontribusi dengan rendahnya prevalensi tersebut.

Kesulitan tersebut dapat muncul dari bayi, ibu, maupun lingkungan sekitarnya di awal periode postpartum. Ibu yang melahirkan bayi prematur dan BBLR memiliki perasaan negatif ketika menyusui seperti cemas, rasa lelah, bersalah, sedih serta takut saat menggendong dan menyentuh bayinya. ${ }^{9-12}$ Perasaan negatif yang muncul menimbulkan stres psikologis yang dapat menyebabkan kegagalan menyusui pada bayi prematur. ${ }^{12}$ Pengaruh budaya lokal juga memengaruhi praktik pemberian ASI pada bayi BBLR di Indonesia. Provinsi Jawa Timur, khususnya kota Malang, sebagian besar penduduknya adalah suku Jawa sehingga budaya Jawa ikut memengaruhi dalam praktik menyusui. Anjuran atau larangan makanan-minuman, perilaku dan kepercayaan untuk ibu menyusui, seperti mandi keramas dengan mata terbuka atau mandi wuwung, minum ramuan herbal untuk menyusui yang terbuat dari campuran akar-akaran seperti kunyit, jahe, temulawak, atau yang masyarakat Malang menyebutnya 'jamu gejah' (jamu kunyit asam), bayi rewel tanda ASI tidak cukup sehingga perlu ditambah makanan pendamping ASI (MPASI), dan lain-lain. Baik anjuran maupun larangan tersebut memiliki peran dalam menyusui, khususnya dipercaya keluarga mampu melancarkan produksi ASI, meningkatkan kesehatan ibu dan bayi sehingga ibu dianjurkan tetap melaksanakan tradisi tersebut meskipun hal tersebut membuat ibu kurang nyaman. Lingkungan sosial juga memengaruhi ibu dalam menyusui, seperti semakin banyak ibu bekerja, promosi susu formula dan pengaruh tetangga dalam memberikan MPASI dini sehingga keputusan ibu untuk tetap menyusui atau tidak menjadi sangat penting. 13-15

Penelitian yang telah ada terkait menyusui bayi BBLR masih berdasarkan pada perspektif ibu di Amerika dan Asia Timur. ${ }^{7,9,10,16}$ Namun, belum terdapat penelitian terkait menyusui pada bayi BBLR berdasarkan perspektif lingkungan sosial dan budaya ibu di Indonesia. Oleh karena itu, tujuan dari penelitian ini adalah untuk mengeksplorasi makna pengalaman ibu untuk tetap menyusui bayi dengan BBLR di kota Malang.

\section{Metode}

Penelitian ini menggunakan desain kualitatif dengan pendekatan fenomenologi. Fenomenologi yaitu suatu cara untuk menggambarkan suatu fenomena berdasarkan pengalaman kehidupan pribadi seseorang yang didapatkan melalui mendengar, melihat, mempercayai, merasakan, mengingat, memutuskan, mengevaluasi, dan melakukan sesuatu. ${ }^{17}$ Ibu primipara yang pernah melahirkan bayi dengan BBLR di Rumah Sakit Dr. Saiful Anwar Malang pernah memberikan ASI, tinggal di wilayah kota Malang, Islam, dan suku Jawa diikutsertakan dalam penelitian ini. Sedangkan partisipan yang tidak diikutsertakan dalam penelitian ini adalah ibu yang memiliki bayi BBLR dengan kontraindikasi menyusui seperti HIV (+), Tuberkulosis aktif yang tidak mendapat terapi. Penelitian ini dilakukan ketika bayi tersebut berusia tiga sampai enam bulan. Pemilihan rentang usia tersebut karena pada usia tiga bulan, ibu postpartum secara psikologis mulai mampu beradaptasi dengan peran barunya dalam menyusui, termasuk jika ibu merupakan perempuan pekerja yang masa cutinya telah habis dan diambil hingga usia enam bulan yang merupakan rentang waktu dari pemberian ASI eksklusif sehingga ingin mengetahui pengalaman ibu menyusui dalam rentang periode pemberian ASI eksklusif.

Pengumpulan data dilakukan dengan wawancara mendalam semiterstruktur, observasi, dan data sekunder pada bulan Mei - Juni 2015. Melalui wawancara semiterstruktur, didapatkan data mengenai pengalaman ibu awal menyusui bayinya ketika di rumah sakit (pengenalan menyusui melalui inisiasi menyusu dini (IMD), Kangaroo Mother Care (KMC), memerah ASI, dan kegiatan rutin menyusui). Selain itu, ditanyakan mengenai pengalaman menyusui di rumah termasuk di dalamnya adalah kesulitan yang dihadapi, usaha mengatasi kesulitan, budaya terkait ibu menyusui, bentuk dukungan yang diberikan oleh keluarga dan lingkungan sekitar. Melalui observasi menyusui, didapatkan data komunikasi dan interaksi antara ibu-bayi-keluarga saat menyusui. Sedangkan melalui data sekunder, didapatkan data demografi ibu dan bayi.

Prosedur pengumpulan data dimulai dengan menghubungi informan kunci seorang bidan yang menangani ibu postpartum di rumah sakit. Informan kunci membantu memberikan informasi bahwa pengambilan data demografi sebaiknya dilakukan melalui laporan register partus dan rekam medik. Tahap selanjutnya adalah mencari data demografi partisipan yang sesuai dengan kriteria melalui data sekunder tersebut. Setelah didapatkan partisipan yang sesuai dengan kriteria, selanjutnya meminta bantuan informan kunci menghubungi partisipan perihal kesediaan dalam penelitian melalui telepon. Setelah partisipan setuju, kemudian 
Tabel 1. Karakteristik Partisipan Ibu Menyusui Bayi BBLR

\begin{tabular}{|c|c|c|c|c|c|c|c|c|}
\hline \multirow{2}{*}{ Kode } & \multirow{2}{*}{ Usia } & \multirow{2}{*}{ Pendidikan } & \multirow{2}{*}{ Pekerjaan } & \multicolumn{2}{|c|}{ Data Bayi } & \multirow{2}{*}{ Menyusui } & \multirow{2}{*}{$\begin{array}{l}\text { Menyusui Eksklusif } \\
\text { (ASI saja) }\end{array}$} & \multirow{2}{*}{$\begin{array}{l}\text { Keluarga yang Tinggal } \\
\text { Serumah }\end{array}$} \\
\hline & & & & Usia & Berat Lahir & & & \\
\hline P1 & 21 tahun & SMA & Karyawan (mall) & 5 bulan & 1.640 gram & Ya & $\begin{array}{l}\text { Tidak, dicampur } \\
\text { susu formula }\end{array}$ & $\begin{array}{l}\text { Suami, anak, budhe, } \\
\text { sepupu } 1 \text { orang dan kakek }\end{array}$ \\
\hline P2 & 20 tahun & SMA & IRT & 4 bulan & 2.140 gram & Ya & $\begin{array}{l}\text { Tidak, dicampur } \\
\text { susu formula dan pisang }\end{array}$ & $\begin{array}{l}\text { Suami, anak, ayah mertua, } \\
\text { dan ibu mertua }\end{array}$ \\
\hline P3 & 20 tahun & SMP & IRT & 6 bulan & 1.592 gram & $\begin{array}{l}\text { Tidak, sejak bayi } \\
\text { usia } 2-3 \text { minggu }\end{array}$ & $\begin{array}{l}\text { Tidak, dicampur susu } \\
\text { formula, bubur, dan } \\
\text { pisang }\end{array}$ & $\begin{array}{l}\text { Anak, ayah, ibu, nenek, } \\
\text { adik kandung } 1 \text { orang, } \\
\text { adik angkat } 1 \text { orang, } \\
\text { suami (kerja ke Bali) }\end{array}$ \\
\hline P4 & 38 tahun & $\mathrm{S} 1$ & Guru les privat & 3 bulan & 2.212 gram & Ya & $\begin{array}{l}\text { Tidak, dicampur susu } \\
\text { formula }\end{array}$ & $\begin{array}{l}\text { Suami, anak, ibu mertua, } \\
\text { adik ipar } 2 \text { orang, dan } \\
1 \text { orang keponakan }\end{array}$ \\
\hline P5 & 19 tahun & SMA & Karyawan (mall) & 6 bulan & 2.480 gram & $\begin{array}{l}\text { Tidak, sejak bayi } \\
\text { usia }<2 \text { bulan }\end{array}$ & $\begin{array}{l}\text { Tidak, dicampur } \\
\text { susu formula, bubur, } \\
\text { dan pisang }\end{array}$ & $\begin{array}{l}\text { Suami, anak, ibu, } \\
\text { ayah, dan adiknya } 2 \text { orang }\end{array}$ \\
\hline P6 & 27 tahun & SD & ART & 3 bulan & 1.950 gram & Ya & $\begin{array}{l}\text { Tidak, dicampur susu } \\
\text { formula, air tajin, } \\
\text { biskuit, bubur }\end{array}$ & $\begin{array}{l}\text { Suami, anak, kedua mer- } \\
\text { tuanya, kakak ipar beserta } \\
\text { istri dan anaknya } 1 \text { orang }\end{array}$ \\
\hline P7 & 32 tahun & SMP & IRT & 6 bulan & 1.592 gram & $\begin{array}{l}\text { Tidak, sejak bayi } \\
\text { usia } 4 \text { bulan }\end{array}$ & $\begin{array}{l}\text { Tidak, dicampur } \\
\text { susu formula, pisang, } \\
\text { dan nasi }\end{array}$ & Suami dan anak \\
\hline
\end{tabular}

Keterangan:

IRT = Ibu Rumah Tangga, ART = Asisten Rumah Tangga

dilakukan kunjungan rumah untuk wawancara mendalam dan observasi. Untuk partisipan kedua dan selanjutnya telah ditentukan dan informan kunci bertugas membantu menghubungi partisipan melalui telepon. Seluruh partisipan mendapat penjelasan mengenai alur penelitian serta menandatangani informed consent. Selain itu, dilakukan permohonan izin kepada partisipan untuk melakukan perekaman dari hasil wawancara. Penelitian ini telah mendapatkan persetujuan dari Komite Etik Fakultas Kedokteran Universitas Gadjah Mada Yogyakarta dengan nomor surat KE/FK/309/EC.

Tujuh orang partisipan bersedia ikut serta dalam penelitian ini. Pengambilan data berhenti pada partisipan ke tujuh karena data yang didapatkan tersaturasi dan tidak terdapat penambahan informasi baru dari jawaban wawancara. Validasi data hasil wawancara dilakukan melalui triangulasi dan observasi menyusui. Triangulasi dilakukan kepada keluarga, bidan ruang postpartum dan dukun bayi. Observasi menyusui dilakukan pada ibu yang ingin menyusui bayinya dan peneliti diizinkan mendampingi ibu saat menyusui. Analisis data menggunakan metode Colaizzi tahun 1978, yaitu dengan cara membaca transkrip hasil wawancara berulang kali, mengidentifikasi pernyataan signifikan, menentukan makna dari pernyataan yang signifikan, mengatur makna ke dalam kelompok tema-tema, menggabungkan hasil tema-tema menjadi deskripsi, memformulasikan fenomena menjadi suatu pernyataan yang jelas, dan memvalidasi kembali data yang dikumpulkan dengan cara menanyakan kembali kepada partisipan tentang data dan tema yang dihasilkan telah sesuai dengan pengalaman partisipan.
Data hasil validasi digabungkan kembali ke dalam deskripsi hasil analisis. ${ }^{17}$

\section{Hasil}

Tujuh orang partisipan yang ikut serta dalam penelitian ini berusia antara $19-38$ tahun, pendidikan bervariasi antara sekolah dasar (SD) - strata 1 (S1), empat partisipan sebagai ibu bekerja, empat partisipan masih menyusui dan tiga lainnya tidak bekerja, dan enam partisipan tinggal bersama keluarga besar. Karakteristik partisipan disajikan pada Tabel 1. Berdasarkan Tabel 1, didapatkan bahwa pada penelitian ini, pemberian ASI eksklusif tidak dilakukan oleh ketujuh partisipan.

Dalam penelitian ini ditemukan empat tema, antara lain pengenalan menyusui sejak dini untuk bayi BBLR, pemberian MPASI dini sebagai alternatif dalam mengatasi kesulitan menyusui, tradisi yang dipercayai dan lingkungan sosial memengaruhi dukungan bagi ibu menyusui, dan menerima menyusui sebagai bagian dari kodrat seorang perempuan. Keempat tema tersebut diperoleh dari pengalaman ibu yang masih menyusui maupun yang telah tidak menyusui saat wawancara.

Pengenalan menyusui sejak dini disampaikan ketujuh partisipan berupa dilakukannya IMD, rawat gabung, memerah ASI, dan KMC selama di rumah sakit.

"Pertama bayinya ditaruh di ruangan dulu...jarak sorenya, sorenya itu baru dipindah terus sama aku (rawat gabung)" (P5).

Tujuh orang partisipan menyampaikan kesulitan selama menyusui yang dialami seperti kelainan puting, bayi menolak menyusu, ibu bekerja, pemberian MPASI dini 
dipilih untuk mengatasi kesulitan tersebut.

"Kira-kira dua bulan. Dikasih pisang sedikit, tiga bulanan lek gak (kalau tidak) salah" (P7).

Pengalaman yang berbeda ditemukan pada keempat partisipan yang masih menyusui saat wawancara, yaitu meskipun merasakan kesulitan dalam menyusui, namun adanya manfaat yang dirasakan bagi diri dan bayinya dari pemberian ASI menjadi alasan keempat partisipan tersebut tetap menyusui.

"Iya gampang mbak, mudah gitu, murah yaa hehehe (sambil tertawa) gak (tidak) pakai biaya” (P4).

Selain manfaat yang dirasakan, juga ditemukan adanya upaya partisipan untuk tetap memberikan ASI khususnya pada partisipan yang bekerja dan masih menyusui.

"Aku sering telat-telat (masuk kerja) itu ya gitu, berangkat gitu, di motor, nganterin dia sambil nyusuin (menyusui)..." (P1).

Tradisi yang dipercayai untuk memperlancar ASI disampaikan ketujuh partisipan berupa anjuran dan pantangan yang berkaitan dengan makanan-minuman, perilaku atau kepercayaan untuk ibu menyusui seperti larangan makan pedas, anjuran makan sayur, mandi banyu wuwung yaitu mandi keramas setiap pagi dengan mata terbuka ketika dialirkan air dari kepala.

"Gak (tidak) boleh makan pedes-pedes gitu aja, pengaruh ke bayinya, buat 'belek'en' (infeksi mata)” (P5).

Pengaruh lingkungan sosial bagi ibu menyusui seperti menggunakan internet untuk mengetahui informasi menyusui, memilih susu formula untuk MPASI serta ibu mengikuti anjuran tetangga/lingkungan sekitar dalam praktik menyusui.

"Orang-orang ndek situ (di situ), kalau, kalau putingnya itu udah pecah, itu gak boleh...diminumkan" (P3).

Dukungan disampaikan partisipan berupa adanya dukungan formal dari tenaga kesehatan dan dukungan informal dari suami, keluarga, dan teman untuk meningkatkan produksi ASI.

"Ya dek e (dia/suami) menyiapkan spet (spuit), menyiapkan kapas, kapas yang sebelum menyusui itu kan dibersihno itu (puting susu)" (P4).

Menerima menyusui sebagai bagian dari kodrat seorang perempuan disampaikan partisipan berupa perasaan bangga, senang, serasa menjadi perempuan seutuhnya.

"Ya memang ngerasain sih, kayak gini ya jadi ibu pas nyusuinnya itu” (P1).

Keterbatasan dalam penelitian ini di antaranya pengambilan data dari data sekunder dan terbatas pada rentang usia tiga sampai enam bulan sehingga jumlah partisipan menjadi terbatas jumlah dan karakteristiknya, pemilihan rentang waktu hingga enam bulan menyusui memungkinkan terjadi recall bias, serta triangulasi tidak dilakukan pada partisipan suami karena beberapa hal seperti kesibukan pekerjaan sehingga dimungkinkan tidak terdapat nilai-nilai dan prespektif suami dalam menyusui bayi BBLR.

\section{Pembahasan}

Pada hasil penelitian, ditemukan empat tema dan bila dibandingkan dengan penelitian sebelumnya, terdapat perbedaan dalam tema yang ditemukan. ${ }^{10,16}$ Perbedaan tersebut adalah adanya tema tentang tradisi yang kuat dan lingkungan sosial dalam memengaruhi dukungan yang diberikan bagi ibu untuk menyusui bayi BBLR di Indonesia.

Bayi BBLR membutuhkan pengenalan menyusu untuk menunjang keberhasilan menyusu. Di awal menyusui muncul perasaan takut, kasihan, tidak percaya, sedih, kaget, tidak tega, kesulitan menggendong, memegang dan menyusui dirasakan oleh partisipan saat melihat bayinya. Hal tersebut serupa dengan beberapa penelitian sebelumnya. 9-12 Pengenalan menyusui dilakukan partisipan melalui IMD, rawat gabung dan KMC. Tidak semua partisipan dilakukan IMD karena kondisi bayinya yang tidak stabil. Partisipan mengeluhkan kesulitan selama melakukan KMC di rumah sakit sehingga ketika di rumah, partisipan tidak melanjutkan melakukan KMC. Untuk melanjutkan KMC, memungkinkan ibu mengalami kesulitan secara fisik dan emosi sehingga membutuhkan bantuan dari anggota keluarga, tenaga kesehatan, atau ibu yang lain. ${ }^{18}$ Rawat gabung juga salah satu upaya mendukung keberhasilan menyusui. Partisipan yang dilakukan rawat gabung menyatakan senang karena ASI lebih lancar dan lebih mudah untuk menyusui bayinya. Hal tersebut sesuai dengan penelitian sebelumnya bahwa ibu merasakan kepuasan dan kebanggaan ketika menyusui di ruang rawat gabung. ${ }^{9}$

Pemberian MPASI dini dilakukan partisipan sebagai alternatif menghadapi kesulitan untuk tetap menyusui. Partisipan mengeluhkan kesulitan seperti kelainan puting (puting terbenam, pecah, terlalu besar, dan lecet), keluarga yang menganjurkan berhenti menyusui dan memberikan MPASI, nyeri karena terlalu sering memompa ASI, dan pekerjaan ibu. Meskipun merasakan kesulitan dalam menyusui, partisipan juga merasakan manfaat menyusui sehingga keempat partisipan memutuskan untuk tetap menyusui. Manfaat yang dirasakan partisipan berupa praktis, hemat, bayi jarang sakit, terdapat ikatan antara ibu-bayi, sebagai obat, dan aman. Hal tersebut serupa dengan penelitian sebelumnya yang menjelaskan manfaat menyusui bagi ibu dan bayi. ${ }^{19}$ Namun, meskipun ketujuh partisipan merasakan manfaat ASI, partisipan tetap memberikan MPASI dini pada bayinya. Partisipan mulai mengenalkan MPASI sejak bayinya berusia dua sampai empat bulan. Alasan pemberian MPASI dini serupa dengan penelitian yang dilakukan di Vietnam dan Brazil. ${ }^{20-21}$ Alasan tersebut agar bayi cepat 
gemuk, ASI sedikit, kurang percaya diri dengan produksi ASI, bayi tampak kurang kenyang dengan ASI, ibu bekerja, usaha pengenalan makanan pada bayi, dan anjuran nenek bayi.

Pelbagai upaya dilakukan partisipan untuk meningkatkan produksi ASI dan mempertahankan menyusui. Upaya untuk meningkatkan produksi ASI seperti sering menyusui dan tidak boleh malas menyusui, konsumsi makanan/minuman yang dipercayai melancarkan ASI seperti susu kedelai, memerah ASI, menyusui dengan bantuan bantal, minum suplemen pelancar ASI, mengeluarkan puting susu yang terbenam dengan spuit. Beberapa partisipan merupakan ibu bekerja sehingga membutuhkan upaya yang lebih untuk mempertahankan menyusui. Namun, partisipan yang bekerja tersebut tidak ada yang memerah ASI di tempat bekerja karena takut meninggalkan pekerjaan dan tidak memiliki waktu untuk memerah ASI meskipun terdapat ruang menyusui. Pemerintah telah membuat peraturan yang mengatur tentang pemberian ASI eksklusif, fasilitas menyusui dan jam menyusui di tempat kerja. Ketersediaan fasilitas dan program pendukung menyusui di tempat kerja meningkatkan tiga sampai enam kali menyusui eksklusif bagi ibu bekerja. ${ }^{22}$ Ibu yang mendukung pemberian ASI eksklusif lima kali berpeluang tetap memberikan ASI eksklusif selama bekerja. ${ }^{23}$

Partisipan menceritakan adanya tradisi yang dipercayai dan lingkungan sosial memengaruhi dukungan bagi ibu menyusui berupa anjuran dan pantangan terkait makanan-minuman, perilaku dan ritual bagi ibu menyusui. Anjuran tersebut seperti makan daun katuk, banyak makan sayur, minum jamu gejah, larangan seperti minum es, makan pedas, ritual yang dianjurkan untuk ibu menyusui khususnya di Jawa Timur dan yang dilakukan partisipan adalah banyu wuwung. Tujuan yang dipercayai adalah untuk menahan darah putih naik ke mata dan untuk meningkatkan produksi ASI, membuat ASI berbau sedap dan tidak amis ketika diminum bayi serta mencegah penyakit bagi bayi.

Berdasarkan triangulasi kepada salah satu dukun bayi di kota Malang, menyebutkan bahwa mandi wuwung, makan sayur, dan minum jamu gejah merupakan hal utama yang harus dilakukan ibu untuk melancarkan ASI. Beberapa kepercayaan terkait kondisi payudara partisipan antara lain ibu dengan puting datar/terbenam tidak dapat menyusui, puting susu yang pecah tidak boleh disusukan karena menyebabkan penyakit dan bayi meninggal serta jika payudara kecil, maka produksi ASI sedikit. Masih terdapat partisipan yang membuang sebagian kolostrum karena berwarna bening dan dianggap tidak bergizi. Pengalaman partisipan di tersebut merupakan sebuah mitos. ${ }^{24}$ Penggunaan galactogogues (zat pelancar ASI) belum terdapat bukti ilmiah kuat yang mendukung. ${ }^{25}$ Hal ini serupa dengan penelitian se- belumnya bahwa ibu menyusui dengan mempertimbangkan keamanan untuk bayi menggunakan herbal galactogogues, namun mereka tetap menginginkan adanya bukti ilmiah akurat dan terpercaya yang mendukung penggunaan herbal sebagai pelancar ASI. ${ }^{26}$

Hasil penelitian ini, salah satu partisipan mengatakan bahwa tidak terdapat pantangan makanan-minuman dan perilaku dari keluarga. Hal itu karena dari pengalaman ibu kandung sebelumnya selama menyusui partisipan, juga tidak pernah ada larangan makanan-minuman, perilaku/ritual di keluarga (dari nenek partisipan). Salah satu partisipan lainnya mengatakan bahwa ibu mertuanya adalah seorang mantan perawat di ruang bayi sehingga tidak mempercayai mitos-mitos terkait menyusui. Pengalaman keluarga sebelumnya akan memengaruhi cara seorang ibu menyusui menyikapi mitos/tradisi yang diturunkan. ${ }^{13-15}$ Hal tersebut sesuai dengan penelitian ini, kedua partisipan merupakan partisipan yang tetap menyusui bayinya. Ibu dan anggota keluarga harus berperan aktif dalam mencari kebenaran tradisi tersebut terdapat justifikasi ilmiah sehingga praktik tersebut tidak merugikan bayi dan ibu.

Lingkungan sosial juga memengaruhi ibu dan keluarga dalam praktik menyusui, dengan memberikan dampak positif dan negatif. ${ }^{13-15}$ Dampak positif seperti partisipan menggunakan media internet untuk mencari informasi seputar kehamilan, persalinan, dan menyusui. Partisipan dengan mudah mendapat informasi menyusui dari mengikuti seminar, penyuluhan, dan buku menyusui. Semakin canggih peralatan telekomunikasi, membuat sebagian besar partisipan berinteraksi saat menyusui dengan menonton televisi atau bermain telepon genggam. Hal tersebut sesuai dengan penelitian sebelumnya yang menunjukkan bahwa ibu primipara Afrika-Amerika sering menggunakan sosial media melalui telepon pintar atau komputer untuk mencari informasi mengenai kehamilan dan setelah persalinan termasuk menyusui. 27

Lingkungan sekitar sangat memengaruhi partisipan dan keluarga dalam menyusui seperti anjuran pemberian air gula karena ASI belum keluar di awal kelahiran, anjuran pemberian susu formula dicampur bubur, dan kelainan puting seperti puting pecah tidak boleh menyusui. Beberapa partisipan mengikuti anjuran dari tetangga dan mulai memberikan MPASI dini. Lingkungan sekitar yang memiliki pengetahuan yang baik tentang menyusui akan mendukung dan memberikan informasi menyusui yang benar dan sesuai kebutuhan partisipan. Hal tersebut sesuai dengan penelitian yang dilakukan oleh Burdette, ${ }^{28}$ pada tahun 2013 yang menyebutkan bahwa tinggal di lingkungan sekitar yang memiliki pengetahuan yang baik tentang menyusui meningkatkan kejadian ibu dalam memulai dan mempertahankan menyusui.

Partisipan menceritakan adanya dukungan untuk 
meningkatkan dan mempertahankan menyusui. Dukungan dari tenaga kesehatan yang mendukung menyusui, merupakan bantuan yang paling efektif untuk ibu menyusui. ${ }^{29}$ Hasil penelitian ini menunjukkan bahwa, dukungan menyusui diterima oleh partisipan dari dokter, perawat, bidan, dan ahli gizi. Partisipan yang masih tetap menyusui mendapat dukungan suami dan yakin dengan produksi ASI-nya. Hal tersebut sesuai dengan hasil penelitian di Kanada dan Indonesia yang menyebutkan bahwa ibu yang mendapatkan dukungan positif dan aktif dari suami, memiliki kepercayaan diri yang tinggi terhadap produksi ASI untuk menyusui serta meningkatkan keputusan dalam mempertahankan menyusui. ${ }^{30,31}$ Keluarga partisipan yang berperan penting dalam memengaruhi partisipan menyusui adalah ibu kandung atau ibu mertua. Nenek bayi memiliki pengaruh yang besar dalam praktik menyusui bagi ibu dan bayi. Suami dan keluarga merupakan sumber dukungan fisik dan emosional yang utama bagi ibu. ${ }^{20}$ Ibu mertua dapat menjadi sumber stres jika mengontrol dan mengkritik kompetensi ibu menyusui. ${ }^{32}$ Konflik juga terjadi ketika salah seorang partisipan seorang ibu bekerja yang ingin tetap memberikan ASI saja, namun keluarga memberikan MPASI tanpa sepengetahuan partisipan kepada bayinya ketika partisian bekerja sehingga partisipan harus menyelesaikan konflik tersebut, seperti dengan mengajak bayi bekerja agar dapat mudah menyusui. Partisipan juga menerima dukungan dari teman sebaya yang sangat mendukung menyusui. Konselor sebaya dan kelompok pendukung ASI juga menjadi pendukung yang efektif. ${ }^{29}$

Partisipan menerima menyusui sebagai bagian dari kodrat seorang perempuan. Menyusui merupakan saat yang ditunggu karena merasa menjadi seorang ibu dan dapat memberikan yang terbaik bagi bayinya. Selain itu, ikatan batin dirasakan ketika ibu berinteraksi dengan bayinya melalui menyusui. Ikatan batin juga dapat meningkatkan kepercayaan diri ibu untuk menyusui. Pada penelitian ini, di awal melahirkan partisipan mengalami kesulitan dalam menyusui dan menyatakan tidak percaya diri hingga putus asa untuk menyusui. Beberapa partisipan merasa yakin untuk menyusui bayinya. Adanya dukungan dari tenaga kesehatan dan keluarga untuk mencoba menyusui serta pengalaman keluarga yang berhasil menyusui membuat beberapa partisipan semakin yakin mampu menyusui dan tetap melanjutkan menyusui. Partisipan yang tidak memiliki percaya diri di awal kelahiran, adanya kesulitan yang dihadapi, dukungan keluarga yang kurang dalam menyusui membuat partisipan menghentikan menyusui bayi kurang dari empat bulan sehingga kepercayaan diri ibu disertai dukungan dari keluarga untuk menyusui akan meningkatkan keinginan dan praktik menyusui pada bayi BBLR.

\section{Kesimpulan}

Menyusui bayi BBLR memiliki tingkat kesulitan yang tinggi. Adanya tradisi yang dipercayai keluarga dan pengaruh lingkungan sosial sangat memengaruhi dukungan yang diberikan kepada ibu dalam menyusui.

\section{Saran}

Bagi tenaga kesehatan, pemberian edukasi menyusui bayi BBLR hendaknya lebih menekankan pada keberlanjutan praktik menyusui ketika di rumah dengan meningkatkan keterlibatan keluarga. Kemudian, diperlukan sebuah kebijakan berupa program tindak lanjut khusus untuk memantau perkembangan dan pertumbuhan bayi BBLR, khususnya selama periode ASI eksklusif. Bagi ibu dan keluarga, hendaknya mencari informasi menyusui yang benar dari tenaga kesehatan dan tidak menerapkan mitos menyusui pada ibu menyusui bayi BBLR.

\section{Ucapan Terima Kasih}

Terima kasih kepada Fakultas Kedokteran Universitas Brawijaya yang telah membantu dalam membiayai penelitian ini.

\section{Daftar Pustaka}

1. World Health Organization (WHO) [homepage di internet]. Care preterm and or low birth weight newborn. 2014 [cited 2014 Sept 14]. Available from: http://www.who.int/maternal_child_adolescent/topics/newborn/care_of_preterm/en/.

2. Kementerian Kesehatan Republik Indonesia. Profil Kesehatan Indonesia Data dan informasi tahun 2013. 2014 [cited 2014 Sep 5]. Available from: www.depkes.go.id/resources/download/pusdatin/profil-kesehatan-indonesia/profil-kesehatan-indonesia-2012.pdf.

3. World Health Organization [homepage di internet]. Guidelines on optimal feeding of low birth-weight infants in low- and middle-income countries. 2011 [cited 2014 Aug 5]. Available from: http://www.who.int/maternal_child_adolescent/documents/infant_feeding_low_bw/en/.

4. Agrasada GV, Ewald U, Kylberg E, Gustafsson J. Exclusive breastfeeding of low birth weight infants for the first six months: infant morbidity and maternal and infant anthropometry. Asia Pacific Journal of Clinical Nutrition [serial on internet]. 2007 [cited 2014 Sept 26]; 20: 62-8. Available from: http://www.ncbi.nlm.nih.gov/pubmed/21393112.

5. Lawrence RA, Lawrence RM. Breastfeeding: a guide for the medical profession. 7th ed. Missouri: Mosby Elsevier Inc; 2011.

6. Quigley M, McGuire W. Formula versus donor breast milk for feeding preterm or low birth weight infants. The Cochrane Database of Systematic Reviews [serial on internet]. 2014 [cited 2015 May 5]; 4, CD002971. Available from: http://www.ncbi.nlm.nih.gov/ pubmed/24752468.

7. Mamemoto K, Kubota M, Nagai A, Takahashi Y, Kamamoto T, Minowa $\mathrm{H}$, et al. Factors associated with exclusive breastfeeding in low birth weight infants at nicu discharge and the start of complementary feeding. Asia Pacific Journal of Clinical Nutrition [serial di internet]. 2013 [cited 2014 Aug 13]; 201322: 270-5. Available from: http://www.ncbi. 
nlm.nih.gov/pubmed/23635373.

8. Badan Penelitian dan Pengembangan Kesehatan Kementerian Kesehatan Republik Indonesia. Riset kesehatan dasar tahun 2013. Jakarta: Badan Penelitian dan Pengembangan Kesehatan Kementerian Kesehatan Republik Indonesia; 2013.

9. Davim RMB, Enders BC, da Silva RAR. Mothers' feelings about breastfeeding their premature babies in a rooming-in facility. Revista da Escola de Enfermagem da USP [serial on internet]. 2010 [cited 2014 Aug 5]; 44: 713-8. Available from: http://www.ncbi.nlm.nih.gov/ pubmed/20961034.

10. Lee TY, Lee TT, Kuo SC. The experiences of mothers in breastfeeding their very low birth weight infants. Journal of Advanced Nursing [serial on internet]. 2009 [cited 2014 Aug 5]; 65: 2523-31. Diunduh dalam: http://www.ncbi.nlm.nih.gov/pubmed/19824911.

11. Padovani FHP, Duarte G, Martinez FE, Linhares MBM. Perceptions of breastfeeding in mothers of babies born preterm in comparison to mothers of full-term babies. The Spanish Journal of Psychology [serial on internet]. 2011 [cited 2014 Aug 4]; 14: 884-98. Available from: http://www.ncbi.nlm.nih.gov/pubmed/22059333.

12. Zanardo V, Gambina I, Begley C, Litta P, Cosmi E, Giustardi A, et al. Psychological distress and early lactation performance in mothers of late preterm infants. Early Human Development [serial on internet]. 2011 [cited 2014 Dec 4]; 87: 321-3. Available from: http://www.ncbi.nlm.nih.gov/pubmed/21316877.

13. Chapman L, Durham RF. Maternal-newborn nursing: the critical components of nursing care. Philadelphia: FA Davis Company; 2010.

14. Klossner NJ, Hatfield NT. Introductory maternity \& pediatric nursing. 2nd ed. Philadelphia: Lippincot Williams \& Wilkins; 2010.

15. Soetjiningsih. ASI: petunjuk untuk tenaga kesehatan. Jakarta: Penerbit Buku Kedokteran EGC; 2013.

16. Rossman B, Kratovil AL, Greene MM, Engstrom JL, Meier PP. I have faith in my milk: the meaning of milk for mothers of very low birth weight infants hospitalized in the neonatal intensive care unit. Journal of Human Lactation [serial on internet]. 2013 [cited 2015 Apr 5]; 29: 359-65. Available from: http://www.ncbi.nlm.nih.gov/pubmed/ 23599267.

17. Polit DF, Beck CT. Essentials of nursing research appraising evidence of nursing practice. 8th ed. Philadelphia: Lippincot Williams \& Wilkins; 2014.

18. Seidman G, Unnikrishnan S, Kenny E, Myslinski S, Cairns-Smith S, Mulligan B, et al. Barriers and enablers of kangaroo mother care practice: a systematic review. PloS One [serial on internet]. 2015 [cited 2015 Feb 5]; 10, e0125643. Available from: http://www.ncbi.nlm. nih.gov/pmc/articles/PMC4439040.

19. Mauri PA, Zobbi VF, Zannini L. Exploring the mother's perception of latching difficulty in the first days after birth: an interview study in an Italian hospital. Midwifery [serial on internet]. 2012 [cited 2015 Jan 24]; 28: 816-23. Available from: http://www.ncbi.nlm.nih.gov/ pubmed/22079624.

20. Nguyen PH, Menon P, Ruel M, Hajeebhoy N. A situational review of infant and young child feeding practices and interventions in Vietnam. Asia Pacific Journal of Clinical Nutrition [serial on internet]. 2011; 20: 359-74. Available from: http://www.ncbi.nlm.nih.gov/ pubmed/21859654.

21. Lindsay AC, Machado MT, Sussner KM, Hardwick CK, Peterson KE.
Infant-feeding practices and beliefs about complementary feeding among low-income Brazilian mothers: a qualitative study. The Food and Nutrition Bulletin [serial on internet]. 2008 [cited 2015 May 5]; 29: 15-24. Available from: http://www.ncbi.nlm.nih.gov/ pubmed/18510201.

22. Basrowi RW, Sulistomo AB, Adi NP, Vandenplas Y. Benefits of a dedicated breastfeeding facility and support program for exclusive breastfeeding among workers in Indonesia. Pediatric Gastroenterology, Hepatology \& Nutrition [serial on internet]. 2015 [cited 2015 Feb 5]; 18: 94-9. Available from: http://www.ncbi.nlm.nih.gov/pubmed/26157694.

23. Abdullah GI, Dian A. Determinan perilaku pemberian air susu ibu eksklusif pada ibu pekerja. Kesmas: Jurnal Kesehatan Masyarakat Nasional [serial on internet]. 2013 [cited 2015 Feb 5]; 7 (7): 298-303. Tersedia pada http://jurnalkesmas.ui.ac.id/index.php/kesmas/article/ view/27/28.

24. Prawindarti L. 50 mitos \& fakta tentang asi dan menyusu [online]. 2013 [cited 2015 Feb 5]. Available from: http://aimi-asi.org/50-mitos-faktatentang-asi-dan-menyusui.

25. Mortel M, Mehta SD. Systematic review of the efficacy of herbal galactogogues. Journal of Human Lactation [serial on internet]. 2013 [cited 2015 Feb 5]; 29: 154-62. Available from: http://www.ncbi.nlm. nih.gov/pubmed/23468043.

26. Sim TF, Hattingh HL, Sherriff J, Tee LBG. Perspectives and attitudes of breastfeeding women using herbal galactagogues during breastfeeding: a qualitative study. BMC Complementary and Alternative Medicine [serial on internet]. 2014 [cited 2015 Aug 4]; 14: 216. Available from: http://www.ncbi.nlm.nih.gov/pubmed/24985246.

27. Asiodu IV, Waters CM, Dailey DE, Lee KA, Lyndon A. Breastfeeding and use of social media among first-time African American mothers. Journal of Obstetric, Gynecologic, \& Neonatal Nursing [serial on internet]. 2015 [cited 2015 Aug 12]; 44: 268-78. Available from: http://www.ncbi.nlm.nih.gov/pubmed/25712127.

28. Burdette AM. Neighborhood context and breastfeeding behaviors among urban mothers. Journal of Human Lactation [serial on internet]. 2013 [2015 Sept 5]; 29: 597-604. Available from: http://www.ncbi. nlm.nih.gov/pubmed/23855026.

29. Clifford J, McIntyre E. Who supports breastfeeding? breastfeeding review. 2008 [2015 Aug 5]); 16: 9-19. Available from: http://www.ncbi.nlm.nih.gov/pubmed/18767233.

30. Februhartanty J, Wibowo Y, Fahmida U, Roshita A. Profiles of eight working mothers who practiced exclusive breastfeeding in Depok, Indonesia. Breastfeeding Medicine [serial on internet]. 2012 [cited 2014 Jan 4]; 7: 54-9. Available from: http://www.ncbi.nlm.nih. gov/pubmed/21777072.

31. Mannion CA, Hobbs AJ, McDonald SW, Tough SC. Maternal perceptions of partner support during breastfeeding. International Breastfeeding Journal [serial on internet]. 2013 [cited 2015 Feb 5]; 8: 4. Available from: http://www.internationalbreastfeedingjournal. com/content/8/1/4.

32. Ong SF, Chan WCS, Shorey S, Chong YS, Klainin-Yobas P, He HG. Postnatal experiences and support needs of first-time mothers in Singapore: a descriptive qualitative study. Midwifery [serial on internet]. 2014 [cited 2015 Feb 25); 30: 772-8. Available from: http://www.ncbi.nlm.nih.gov/pubmed/24161493. 